\title{
A year after the start of COVID-19
}

\author{
Adrian Camacho-Ortiz* \\ Head of Infectious Diseases and Hospital Epidemiology, "Dr. José Eleuterio González" University Hospital, Monterrey, Nuevo Leon, Mexico
}

\section{Introduction}

For the past several years, when giving my usual lecture to medical students, I would exemplify the HIV epidemic as the disease, that in a relatively short time span, more scientific discoveries, adequate treatment options, vaccine development, and prevention strategies were true until December 2019.

The coronavirus disease 2019 (COVID-19) pandemic has tested the human race as no other disease has done in the past, and science has responded in an identical fashion. Within days, the total genome sequencing of what is now called severe acute respiratory syndrome coronavirus-2 (SARS-CoV-2) was available online. Within weeks', hundreds of trials were underway exploring treatment options, diagnosis strategies, and preventive measures. And within months', effective vaccines are being used worldwide. In the following paragraphs, I offer a concise analysis of the past year and my personal perspective for the days to come.

\section{Key elements in viral structure and evolution}

There are now seven family members of the human coronavirus; these viruses are related to zoonotic transmission; three of them have caused outbreaks and pandemics (SARS-CoV, MERS, and SARS-CoV-2). Progenitors of SARS-CoV evolved through recombination within Rinolophus bats and then transmitted to farm civets (Paguma larvata), which transmitted it to market civets substantial mutations ultimately transmitted it to humans ${ }^{1}$. Protein sequencings have also linked pangolins, snakes, and turtles as intermediate hosts due to the presence of ACE2 receptors. Both SARSCoV-2 and bat-related coronavirus have highly similar nucleotide sequences and show common genetic ancestry ${ }^{2}$.

Four major structural proteins: the spike (S), membrane $(M)$, envelope $(E)$, and nucleocapsid $(N)$ have been described. The spikes are membranous glycoprotein projections that constitute peplomers, induce neutralizing antibodies, and play a significant role in the pathogenesis of SARS-CoV-2. The M-protein is the most abundant protein of the membrane bilayer and maintains the shape of the virion. The E-protein is a valine and leucine-rich hydropathic transmembrane protein essential for viral pathogenesis. These proteins are the main focus of serologic testing and vaccine targeting ${ }^{3}$.

\section{Viral mutations and lineages}

Global dissemination of SARS-CoV-2 has invariably resulted in tens of thousands of mutations, many of which are not clinically significant. We now know that the D614G mutation in the S-protein is the most prevalent globally. New variants are emerging and increasing concern about their clinical and immunologic implications.

The United Kingdom (UK) variants are named 20I/501Y.V1, VOC 202012/01, (or B.1.1.7) have emerged 
Table 1. Brief description of currently available vaccines against SARS-CoV-2, characteristics, effectiveness, and development phase

\begin{tabular}{|l|l|c|l|l|l|}
\hline Platform & Type & $\begin{array}{c}\text { Required } \\
\text { doses }\end{array}$ & $\begin{array}{l}\text { Pharmaceutical } \\
\text { Company }\end{array}$ & Effectiveness & Storage \\
\hline RNA & LNP-mRNA & 2 & Moderna/NIAID & $94.5 \%$ & $-20^{\circ} \mathrm{C}$ \\
\hline RNA & LNP-mRNAs & 2 & Pfizer/BioNTech & $95 \%$ & $-70^{\circ} \mathrm{C}$ \\
\hline $\begin{array}{l}\text { Non-replicating } \\
\text { viral vector }\end{array}$ & ChAd0 $\times 1-S$ & 2 & Oxford/Astra-Zeneca & $62-90 \%$ & $2-8^{\circ} \mathrm{C}$ \\
\hline $\begin{array}{l}\text { Non-replicating } \\
\text { viral vector }\end{array}$ & Ad26 & 1 & Jassen & $85 \%$ for severe disease & $2-8^{\circ} \mathrm{C}$ \\
\hline $\begin{array}{l}\text { RNA } \\
\text { and } 100 \% \text { for death }\end{array}$ & Phase 2b/3 underway & --- \\
\hline $\begin{array}{l}\text { Protein subunit } \\
\text { LNP-mRNAs }\end{array}$ & $\begin{array}{l}\text { Recomb. protein/ } \\
\text { AS03 }\end{array}$ & 2 & Curevac & $\begin{array}{l}\text { Currently evaluating } \\
\text { phase } 2 / 3\end{array}$ & --- \\
\hline $\begin{array}{l}\text { Non-replicating } \\
\text { viral vector }\end{array}$ & AdV5 & 2 & Cansino & $88-90 \%$ (fase2) & $2-8^{\circ} \mathrm{C}$ \\
\hline $\begin{array}{l}\text { Non-replicating } \\
\text { viral vector }\end{array}$ & rAd26 y rAd5 & 2 & Sputnik & $91.6 \%$ & $2-8^{\circ} \mathrm{C}$ \\
\hline
\end{tabular}

in late 2020, and have since been detected in numerous countries worldwide, including the United States and Mexico. Evidence suggests that the B.1.1.7 variant could be associated with an increased risk of death compared with other variants ${ }^{4}$, although studies are underway.

The South Africa variant of SARS-CoV-2 (known as $20 \mathrm{H} / 501 Y . V 2$ or B.1.351) emerged independently of B.1.1.7. This variant shares some mutations with B.1.1.7. Cases attributed to this variant have been detected in multiple countries outside of South Africa.

In Brazil, a variant known as P.1, which was first identified in travelers from Brazil to Tokyo, Japan. This variant has 17 unique mutations, including three in the receptor-binding domain of the spike protein. There is rapid emerging evidence on the implications of these and other variants. The reader is prompted to review emerging data continuously 5 .

\section{Exploring treatment options}

Many studies have failed to find a treatment regimen that is effective in reducing mortality. The only strong evidence to date is the use of dexamethasone for patients with the need for supplementary oxygen (https:// www.recoverytrial.net/results/dexamethasone-results). However, this is still a rudimentary treatment for an inflammatory phase of the disease. To date, there are no effective antivirals that can be given early in the course of the disease that effectively halts disease progression. Remdesivir ${ }^{6}$ and the combination of remdesivir plus baricitinib (a JAK 1,2 inhibitor) ${ }^{7}$ have shown benefit in recovery time. Monoclonal antibodies also have reduced viral load in outpatients ${ }^{8}$ and have paved the way for early treatment strategies that might have a substantial impact in reducing disease burden and hospitalization. Tocilizumab has failed to demonstrate beneficial effects regarding mortality and only reduced ICU stay in one study (COVACTA). Ongoing trials are now looking for its potential role in the disease (if any), and to this date, data are confusing 9 .

\section{Currently available vaccines}

Science and outbreaks such as SARS, influenza 2009, and Ebola, among others, have paved the way for the unprecedented speed at which vaccination has been delivered in any disease in history. Delivery systems such as non-replicate adenoviruses vectors and mRNA/lipid nanoparticle-based vaccines have been crucial in the response time for an effective population-based vaccine strategy. The first FDA approved vaccine $\left(\mathrm{Pfizer}^{\circledR}\right)$ has been applied in multiple countries for health-care personnel and for vulnerable populations. Astra-Zeneca's candidate has followed closely, both with overall great success and a minimum of severe adverse effects. Other vaccines are now starting to be used in many countries (Table 1). In general, all of them have excellent results for generating cellular and/or humoral response (> 90\%). Although safe and 
effective to date, questions remain for the long run, how long will immunity last? Will combining different vaccines have a positive effect? What will be the frequency of revaccination? Among other queries.

\section{Perspective}

There is no way around the fact that COVID-19 is here to stay. There will be a see-saw of epidemiologic curves until widespread vaccination reaches over $60 \%$ of the population, and even when this occurs, variants of the strains will show various degrees of susceptibility to the available vaccines, and booster doses and revaccination strategies with variant strains will be everyday phenomenon; something similar to the yearly influenza vaccination in which regional circulating strains are included in a periodic vaccination scheme. The immunity acquired with subsequent infections over a prolonged period of time is something to explore; through repeated exposure and infection, disease severity would have a tendency to lessen with every reinfection. Vaccination with novel technology vaccines such as mRNA based and adenovirus vector based is impressive developments that can ultimately help stop the pandemic. Although they have been approved for emergency use, they have not passed the test of time. Furthermore, we are unsure of the potential additive or booster phenomenon that will emerge when applying subsequent different types of vaccines (for example, using one dose of mRNA based vaccine then using an adenovirus vector-based one). Hope is very strong, and only through science, we as a species will prevail.

\section{Conflicts of interest}

The author has no conflicts of interest.

\section{References}

1. Wu F, Zhao S, Yu B, Wang W, Song ZG, Hu Y, et al. A new coronavirus associated with human respiratory disease in China. Nature. 2020;579:265-9

2. Boni MF, Lemey P, Jiang X, Lam TT, Perry BW, Castoe TA, et al. Evolutionary origins of the SARS-CoV-2 sarbecovirus lineage responsible for the COVID-19 pandemic. Nat Microbiol. 2020;5:1408-17.

3. Bianchi M, Benvenuto D, Giovanetti M, Angeletti S, Ciccozzi M, Pascarella S. Sars-CoV-2 envelope and membrane proteins: structural differences linked to virus characteristics? Biomed Res Int. 2020;2020:4389089

4. Horby P, Huntley C, Davies N. NERVTAG note on B.1.1.7 Severitypdf Iconexternal Icon. SAGE Meeting Report, January 21; 2021.

5. Centers fro Diseas Control and Prevention. Science Brief: Emerging SARS-CoV-2 Variants. Available from: https://www.www.cdc.gov/coronavirus/2019-ncov/more/science-and-research/scientific-brief-emerging-variants.html. [Last accessed on 2021 Feb 02]

6. Beigel JH, Tomashek KM, Dodd LE, Mehta AK, Zingman BS, Kalil AC, et al. Remdesivir for the treatment of Covid-19 final report. N Engl J Med. 2020;383:1813-26.

7. Kalil AC, Patterson TF, Mehta AK, Tomashek KM, Wolfe CR Ghazaryan V, et al. Baricitinib plus remdesivir for hospitalized adults with Covid-19. N Engl J Med. 2020;11:NEJMoa2031994.

8. Weinreich DM, Sivapalasingam S, Norton T, Ali S, Gao H, Bhore R, et al. REGN-COV2, a neutralizing antibody cocktail, in outpatients with Covid-19. N Engl J Med. 2021;384:238-51.

9. McCreary EK, Meyer NJ. Covid-19 controversies: the tocilizumab chapter. BMJ. 2021;27:372 